\title{
INFLUENCE OF COEFFICIENT VARIATION ON THE VALUE OPTIMAL LEVEL OF MAINTENANCE
}

Complex technical objects in modern society are extremely important. Such objects belong to the class of recoverable objects of long-term repeated use. They tend to be expensive and costly to operate. To ensure the required level of reliability during their operation, maintenance is usually carried out, the essence of which is the timely preventive replacement of elements that are in a pre-failure state. A characteristic feature of complex technical objects for special purposes is the presence in their composition of a large number (tens, hundreds of thousands) of different types of component parts that have different levels of reliability, different patterns of their wear and tear processes. This feature requires a more subtle approach to the organization and planning of maintenance during their operation.

The problem is that during the development of such facilities, all issues related to maintainability and maintenance should be addressed already at the early stages of facility design. If you do not provide in advance the necessary hardware and software for the built-in monitoring of technical condition (TC) of the object, do not develop and "build" the maintenance technology into the object, then it will not be possible to realize in the future a possible gain in the reliability of object due to maintenance. Since all these issues must be resolved at the stage of object creation (when the object does not yet exist), mathematical models of the maintenance process are needed, with the help of which it would be possible to calculate the possible gain in the level of reliability of facility due to maintenance, to estimate the cost costs required for this. Then, based on such calculations, make a decision on the need for maintenance for this type of objects and, if such a decision is made, develop structure of the maintenance system, choose the most acceptable maintenance strategy, and determine its optimal parameters. In this paper, we study the influence of the coefficient variation on value of the optimal level of maintenance. The work also confirms the general idea that the smaller value of the coefficient variation of random operating time to failure of the serviced elements, greater optimal value of maintenance level should be.

Keywords: maintenance, coefficient of variation, facility reliability, component parts.

Introduction. Complex technical objects in modern society are extremely important. We are talking primarily about various radio-electronic complexes for military and special purposes, radar stations, automated control systems (air traffic, energy facilities, etc.). The state's defense capability, economic security, and the lives of hundreds and thousands of people depend on the level of reliability such facilities.

Complex technical objects are understood as objects consisting of a large number different types of elements (tens, hundreds of thousands), each of which can represent a rather complex technical device. Elements can be electronic, mechanical, electromechanical, hydraulic, etc. The diversity of elements leads to the fact that different elements are characterized by fundamentally different physical processes (and, consequently, rates) of degradation, leading to their failures.

Objects can have an arbitrary reliability structure (as a rule, serial-parallel). The structural structure of such objects is usually hierarchical, that is, the object consists of subsystems, subsystems consist of units (cabinets), units - of devices (blocks), etc.

Analysis of previous studies. The "surge" in number of theoretical works on the maintenance of complex systems falls on the 70-s of the last century, which can be explained by the mass production of complex radio-electronic equipment for military and special purposes at that time [16]. Currently, there is a decline in the number of scientific publications devoted to the maintenance of complex technical objects. One of the reasons for this, in our opinion, is the sharp increase in the level of integration and reliability of components. Thanks to this, the developers of sophisticated 
equipment were able to solve the issues of ensuring the required level of reliability without significant maintenance costs (or without maintenance at all). However, the same reason (high integration and reliability of component parts) opened up the possibility of implementing more and more complex technology with new functions, which was impossible with the old element base. This again leads objectively to the problems of ensuring reliability and, therefore, the question of need for maintenance and the choice of optimal strategy for its implementation again becomes relevant.

Formation of problem. Unfortunately, the currently known mathematical models and methods for calculating the optimal parameters of maintenance processes are not very suitable for application to real technical objects. The main disadvantage of these models is that they either do not take into account the complex structure of an object at all, or it is possible to take into account only some of the simplest structures [7, 8]. In [9], a comparative analysis of the problems arising in solving the problems of maintenance "by resource" and "by state" is made. An overview of the latest work for that period in field of maintenance and repair of complex systems is given. In [10], a theoretical generalization of the known mathematical models of maintenance processes is made. However, these models do not allow constructing methods suitable for practical use on their basis.

In our opinion, the situation is even worse with mathematical models of maintenance processes "by state". Only a small number of scientific works are devoted to this area of research $[11,12]$.

Main part. From simple physical considerations, it is clear that the choice of the optimal level of maintenance $u_{\text {то } i}$ should depend on the statistical properties of determining parameter of $i$-th element. Obviously, the main characteristic, on which the choice of the optimal value $u_{\text {то } i}$ depends, is the coefficient of variation $v_{u i}$ determining parameter. The smaller value $v_{u i}$, larger the optimal value $u_{\text {то } i}$ should be.

In the developed ISS, $D N$-distribution is used as a model for failures of serviced elements. A feature of $D N$-distribution is that the coefficient of variation $v_{i}$ distribution is equal to the coefficient of variation $v_{u i}$ defining parameter of the element, the failures of which generate the given $D N$ distribution [11]. This fact greatly simplifies the study of the properties of optimal maintenance $u_{\mathrm{To} i}^{*}$ levels. Let us investigate how the optimal value on average depends on the coefficient of variation serviced elements. The study will be carried out in MC simulation mode with a constant monitoring frequency. For all serviced elements, we will set the same values of the coefficient of variation $v_{i} \equiv v$ operating time to failure, and determine the same optimal value $u_{\mathrm{ro} i}^{*} \equiv u_{\mathrm{To}}^{*}$. The optimal value $u_{\mathrm{To}}^{*}$ will be determined by the criterion

$$
u_{\mathrm{To}}^{*}: c_{\text {уд }}\left(E_{\mathrm{To}}, u_{\mathrm{To}}, T_{\mathrm{\kappa}}\right) \rightarrow \min _{u_{\mathrm{ro}}}
$$

where the parameters and are fixed. The set is a characteristic of object, the parameter will vary in a certain range.

For the study, special software has been developed that allows us to obtain the dependence of the indicator on the parameters of interest to us. The calculation results are obtained in the form of the corresponding graphs.

The study will be carried out using the example of test object Test- 1 . In database for Test-1 object, we will sequentially set different values of the coefficient of variation $v$ of the distribution of the operating time to failure of the structural elements lower level. Then, for each value $v$, we will make calculations in order to determine the optimal value of the maintenance $u_{\text {то }}^{*}$ level according to criterion (1).

We will make variations $u_{\text {то }}$ in range $[0,1 ; 0.96]$ with an interval of 0.02 . We will make 
calculations under the condition that the set $E_{\text {то }}=\{132,12,11111\}$, for three values of the monitoring frequency $T_{\mathrm{\kappa}}: 500 \mathrm{~h}, 1000 \mathrm{~h}$ and $1500 \mathrm{~h}$.

In fig. 1 shows graphs of dependence unit operating cost $c_{\text {уд }}\left(E_{\text {то }}, u_{\text {то }}, T_{\mathrm{K}}\right)$ on $u_{\text {то }}$ at $T_{\mathrm{K}}=1000$ $\mathrm{h}$ for three values of the coefficient of variation: $v: 0.1 ; 0.5 ; 1.0$.
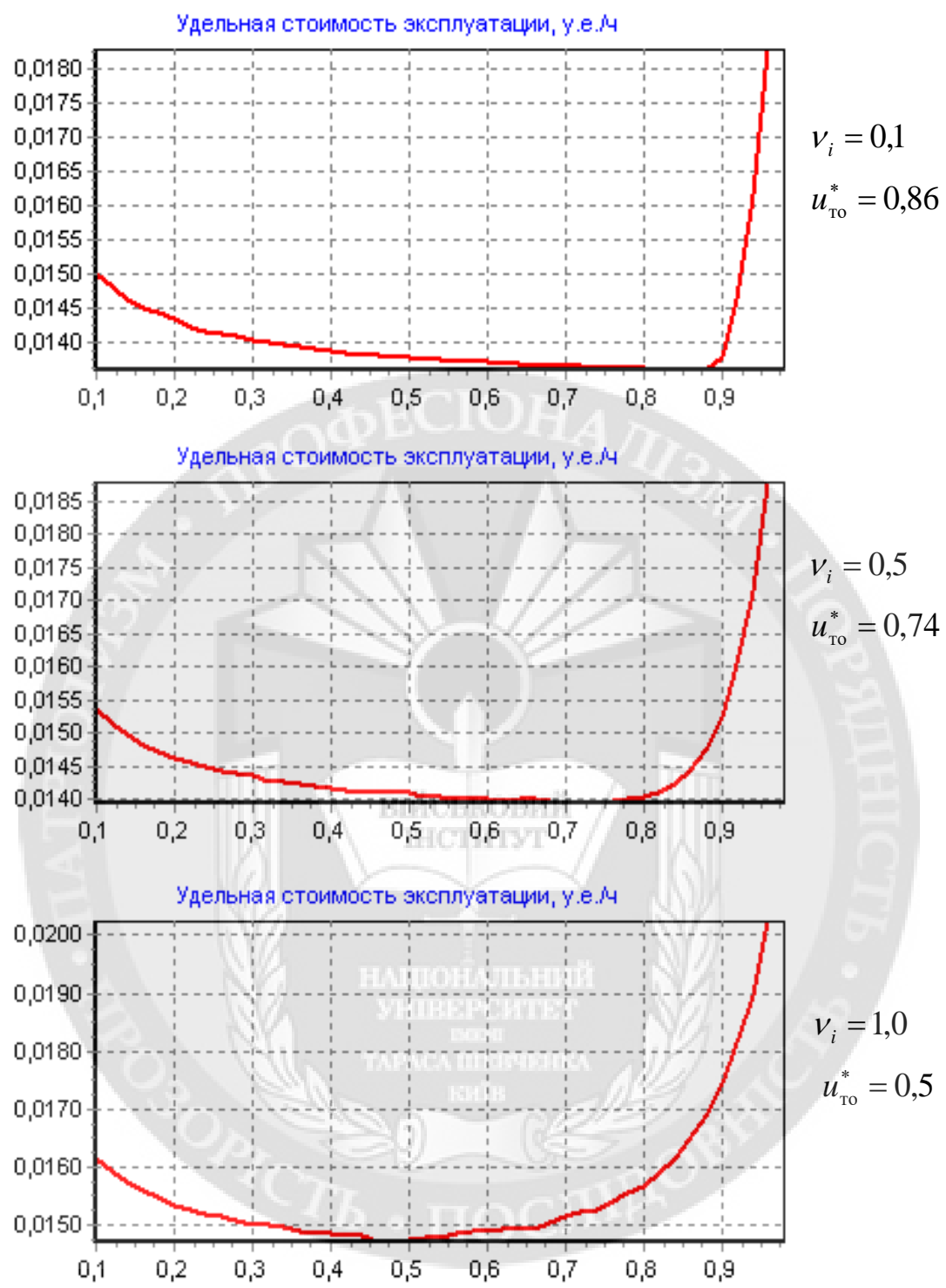

Figura 1 - Graphs of dependence $c_{\text {уд }}$ on level of maintenance $u_{\text {то }}$ at various values $v_{i}$ (object Test-1, $T_{\mathrm{\kappa}}=1000 \mathrm{~h}$ )

The graphs show that with an increase in the coefficient of variation $v$, optimal value of the maintenance $u_{\text {то }}^{*}$ level shifts to the region of lower values.

Graphs fig. 1 are given only to illustrate the type of results obtained. Based on the totality of all calculation results for Test- 1 object obtained in this study, the graphs shown in fig. 2 a. Similar graphs were obtained for other test objects. In general, their nature is similar to the graphs for the Test-1 object. In fig. 2 b shows the same graphs for the Test- 4 object as an example. 


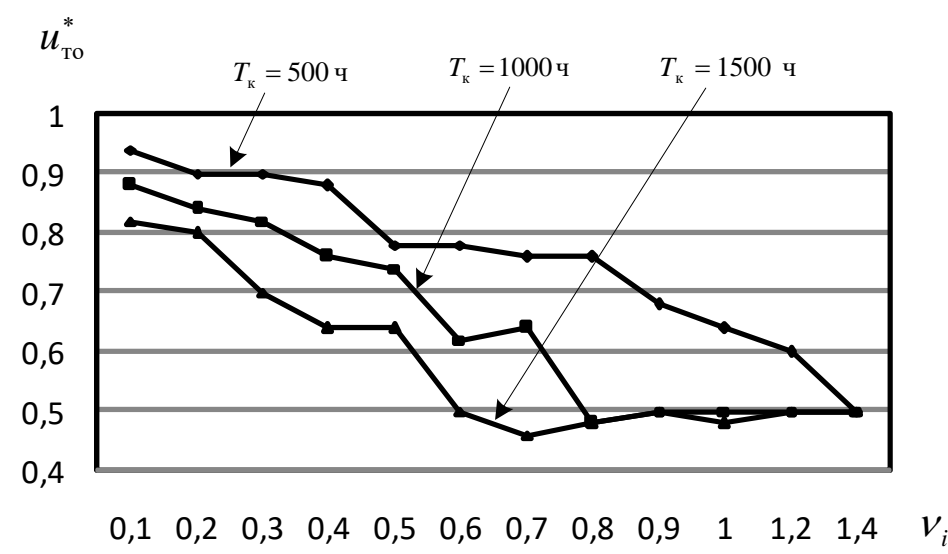

a) Test-1 object

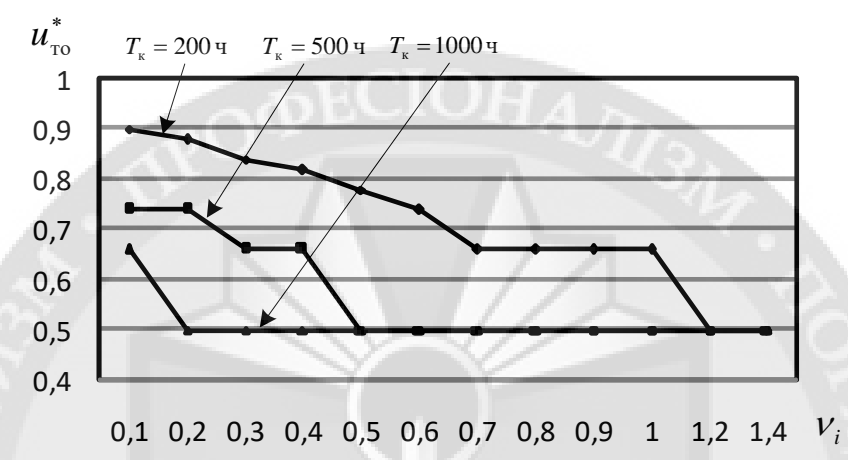

b) Test-4 object

Figura 2 - Graphs of the dependence of optimal level maintenance $u_{\mathrm{To}}^{*}$ on the value of coefficient variation $v_{i}$ for different values of monitoring frequency $T_{\mathrm{K}}$

Conclusions. In general, based on the results of this brief study, following conclusions can be drawn:

- general idea is confirmed that the smaller the value of the coefficient of variation of the random operating time to failure of the serviced elements, the greater the optimal value of the maintenance level $u_{\mathrm{To}}^{*}$ should be;

- since for the serviced elements value $v_{i}$ of the coefficient variation, as a rule, is much less than 1 , the optimal maintenance $u_{\mathrm{ro} i}^{*}$ levels for various elements should be determined separately;

- if coefficients of variation operating time to failure of the serviced elements are close to 1 , the optimal maintenance level for them is b value $u_{\mathrm{ro} i}^{*}=0.5$.

\section{REFERENCES:}

1. Forecasting to reliability complex object radio-electronic texnology and optimization parameter their technical usage with use the simulation statistical models: [monography] in English / Sergey Lenkov, Konstantin Borjak, Gennady Banzak, Vadim Braun, ets.; under edition S.V. Lenkov. - Odessa: Publishing house "VMV", 2014. - $252 \mathrm{p}$.

2. Jason Brown, Lucas Mol On the roots of all-terminal reliability polynomials / Discrete Mathematics, Volume 340, Issue6, June 2017, pages 1287-1299.

3. Lirong Cui, Yan Li, Jingyuan Shen, Cong Lin Reliability for discrete state systems with cyclic missions periods / Applied Mathematical Modtlling, Volumt 40, Issues 23-24, December 2016, Pages 1078310799/

4. Iris Tien, Armen Der Kiureghian Algorithms for Bayesian network modeling and reliability 
assessment of infrastructure systems / Reability Engineering \& System Safety, Volume 156, December 2016, Pages 134-147.

5. Volokh O.P. Methods of substantiation rational values operiodicity of maintenance of machines of engineering armament during operation // Collection of scientific works of Military Institute of Taras Shevchenko National University of Kyiv, 2005. - P. 29-32.

6. Boryak K.F Faultlessness model of a complex recoverable object of electronic equipment // Collection of scientific works of Military Institute of Taras Shevchenko National University of Kyiv: 2009. - № 21. P.33-41.

7. Reliability and efficiency in technology. Directory. Vol.2. Mathematical methods in the theory of reliability and efficiency / Ed. B.V. Gnedenko. M .: Mechanical Engineering, 1988. - 280 p.

8. Computational methods of research and design of complex systems. Mikhalevich V.S., Volkovich V.L. - M .: Science, 1982. $286 \mathrm{~s}$.

9. Braun V.O., Boryak K.F., Lantvoyt O.B., TSytsarev V.N. Modeling of maintenance processes of complex reconstructed objects of radio-electronic equipment // News of the Engineering Academy of Ukraine.K., 2008. - №1. - P. 47 - 52.

10. Boryak K.F. Research of the process of maintenance of complex renewable objects of electronic equipment with the help of simulation statistical model // Bulletin of the Engineering Academy of Ukraine. K., 2008. - №2. - P.85-91.

11. Banzak H.V. Reliability database of complex objects of radio-electronic equipment / H.V.Banzak, K.F.Boryak, V.N.TSytsarev // Collection of scientific works of the Military Institute of Taras Shevchenko National University of Kyiv. - 2010. - № 27. - P.89 - 97.

12. Banzak O.V. Research processes of gamma radiation detector for developing a portable digital spectrometer / O.V. Sieliykov, M.V. Olenev, S.V. Dobrovolskaya, O.I. Konovalenko // Collection of scientific works of the Military Institute of Taras Shevchenko National University of Kyiv. - 2020. - № 69. - P.5 - 13.

к.пед.Н., доц. Толок І.В., к.Т.н., доц. Банзак Г.В., к.т.н., ст. досл. Лснков Є.С., Бондаренко Т.В. ВПЛИВ КОЕФІЦІЕНТА ВАРІАЦІЇ НА ВЕЛИЧИНУ ОПТИМАЛЬНОГО РІВНЯ ТЕХНІЧНОГО ОБСЛУГОВУВАННЯ

Складні технічні об'скти в сучасному суспільстві мають виключно важливе значення. Такі об'єкти відносяться до класу об'єктів, щио відновлюються тривалого багаторазового застосування. Вони, як правило, с дорогими і вимагають значних витрат на їх експлуатацію. Для забезпечення необхідного рівня безвідмовності в процесі їх експлуатації зазвичай проводиться технічне обслуговування (ТО), суть якого полягас у свосчасній заміні, щцо попереджується елементів, що знаходяться в предвідмовному стані. Характерною особливістю складних технічних об'єктів спеціального призначення с наявність в їх складі великої кількості (десятки, сотні тисяч) різнотипних комплектуючих елементів, які мають різний рівень надійності, різні закономірності процесів їх зносу і старіння. Ця особливість вимагає більш тонкого підходу до організації і планування ТО в процесі їх експлуатації.

Проблема полягає в тому, що при розробці таких об'єктів всі питання, пов'язані 3 ремонтопридатністю і технічним обслуговуванням повинні вирішуватися вже на ранніх етапах проектування об'єкта. Якщо не передбачити заздалегідь необхідні апаратні і програмні засоби вбудованого контролю технічного стану (ТC) об'єкта, що не розробити і не "вбудувати" в об'єкт технологію проведення ТО, то реалізувати в майбутньому можеливий виграш в безвідмовності об'єкта за рахунок проведення ТО не вдасться. Оскільки всі ці питання повинні вирішуватися на етапі створення об'єкта (коли об'єкта ще немає), необхідні математичні моделі процесу ТО, за допомогою яких можна було б прорахувати можлливий виграш в рівні безвідмовності об'єкта за рахунок проведення ТО, оцінити необхідні для цього вартісні витрати. Потім на підставі таких розрахунків прийняти рішення про необхідність проведення ТО для даного типу об'єктів $i$, якщчо таке рішення прийнято, розробити структуру системи ТО, вибрати найбільш прийнятну стратегію ТО, визначити ї̈ оптимальні параметри.

У даній роботі проводиться дослідження впливу коефіцієнта варіації на величину оптимального рівня технічного обслуговування. Також в роботі підтверджується загальне міркування про те, цио чим менше величина коефіцієнта варіації випадкової напрацювання до відмови обслуговуються елементів, тим більшим має бути оптимальне значення рівня ТО.

Ключові слова: технічне обслуговування, коефіцієнт варіації, безвідмовність об'єкта, комплектуючі елементи. 